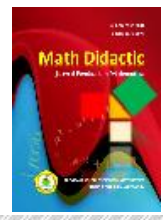

MATH DIDACTIC: JURNAL PENDIDIKAN MATEMATIKA

Volume 5 Nomor 1, Januari - April 2019, halaman 52 - 64

Tersedia Daring pada http://jurnal.stkipbjm.ac.id/index.php/math

\title{
PENINGKATAN HASIL BELAJAR MATEMATIKA MELALUI MODEL PROBLEM BASED LEARNING (PBL) BERBANTUAN CARD SORT SISWA KELAS LIMA
}

\section{THE IMPROVING OF MATHEMATIC LEARNING OUTCOMES THROUGH PROBLEM BASED LEARNING WITH CARD SORT STRATEGY FOR FIFTH GRADE STUDENTS}

\author{
Arini Mayang Fauni, Henny Dewi Koeswanti, Elvira Hosein Radia \\ PGSD FKIP Universitas Kristen Satya Wacana \\ arinifauni@yahoo.com, henny.koeswanti@uksw.edu, elvira.hosein@uksw.edu
}

\begin{abstract}
Abstrak: Tujuan penelitian untuk mendeskripsikan peningkatan hasil belajar matematika bagi siswa SDN Kutowinangun 04 Salatiga kelas 5semester gasal tahun ajaran 2018/ 2019 melalui Problem Based Learning (PBL) berbantuan Card Sort. Penelitian ini adalah penelitian tindakan kelas yang terdiri dua siklus, tiap siklus terdiri dari tiga tahapan yaitu dua kali pertemuan dan satu kali tes yang didasarkan pada tahapan perencanaan, tindakan dan observasi, serta refleksi dan evaluasi. Teknik pengumpulan data dalam penelitian menggunakan 3 jenis yaitu tes, observasi, dan dokumentasi. Data yang diperoleh berupa nilai tes matematika pada akhir siklus I dan pada akhir siklus II. Teknik analisis data dilakukan dengan teknik deskriptif komparatif . Hasil penelitian menunjukkan peningkatan hasil belajar Matematika. Peningkatan hasil belajar siswa dapat dilihat dari nilainya yang mencapai KKM sebelum tindakan 20,68\%, siklus I 44,82\%, dan siklus II 89,65\%. Berdasarkan uraian di atas disimpulkan bahwa penerapan model pembelajaran $P B L$ dalam pembelajaran Matematika dapat meningkatkan hasil belajar Matematika.
\end{abstract}

Kata Kunci: hasil belajar, matematika, Problem Based Learning, Card Sort

\begin{abstract}
The aim of the research is to describe the increasing mathematic scores for students fifth grade at SDN Kutowinangun 04 Term one education year 2018/2019 through Problem Based Learning (PBL) with Card Sort strategy. The research is classroom action research which consisted of two cycles, each cyle would cover two meetings and one time test, there would be stages in every cycle: planning, action and observation, reflection and evaluation. The data gained in formed of mathematic tests in the end of $1^{\text {st }}$ and $2^{\text {nd }}$ cycles. Data analysis technique used was descriptive comparative technique. The result of the research showed that there was a significant improving of Mathematic scores. The improving of students' mathematic learning outcome could be seen from the scores which reached Minimum Criteria of Mastery Learning (KKM) before action 20,68\%, $1^{\text {st }}$ cycle 44,82\%, and $2^{\text {nd }}$ cycle $89,65 \%$. Based on the description above, it could be concluded that the implication of Problem Based Learning with Card Sort Strategy in learning mathematic could increase mathematic scores.
\end{abstract}

Keywords: learning outcomes, mathematics, Problem Based Learning, Card Sort

Cara Sitasi: Fauni, A.M., Koeswanti, H.D., \& Radia, E.H. (2019). Peningkatan hasil belajar matematika melalui model Problem Based Learning (PBL) berbantuan card sort siswa kelas lima. Math Didactic: Jurnal Pendidikan Matematika, 5(1), 52-64. https://doi.org/10.33654/math.v5i1.518

Submitted: March 18, 2019

Revised: April 2, 2019

Published: April 30, 2019

Available Online Since: April 19, 2019 
Pendidikan dalam Undang-Undang No. 20 Tahun 2003 tentang sistem pendidikan nasional adalah bentuk usaha yang terencana dalam merealisasikan proses pembelajaran agar siswa secara aktif mengembangkan potensi diri sehingga memiliki kemampuan keagamaan, pengendalian diri, kepribadian, kecerdasan, serta segala bentuk keterampilan yang yang diperlukan setiap siswa dalam bermasyarakat, berbangsa dan bernegara. Pendidikan juga merupakan proses yang dicapai melalui penciptaan suasana belajar dan proses pembelajaran (Rohman, 2009, hal. 10). Dalam hal ini pendidikan dapat meningkatkan kemampuan siswa melalui pendidikan dalam lingkungan keluarga dan pendidikan formal di sekolah. Pendidikan formal di sekolah selain mencerdaskan kehidupan para siswa, juga berfungsi untuk meningkatkan harkat martabat atau kepribadian para siswa. Oleh sebab itu pendidikan formal terdiri dari pendidikan akademik dan non akademik. Sehingga yang menjadi tolok ukur sebuah keberhasilan dalam proses pembelajaran yakni prestasi belajar setiap siswa.

Suasana yang mestinya tercipta melalui proses pembelajaran adalah siswa terlibat aktif dalam belajar. Kebanyakan dalam proses pembelajaran saat ini berpusat pada guru (teacher-centredness) sebagai sumber belajar, sehingga siswa kurang terlibat aktif dalam proses pembelajaran dan akibatnya tingkat pemahaman siswa terhadap materi pembelajaran menjadi rendah (Gewati, 2018, edukasi Kompas). Cara mendesain pembelajaran yang mampu membuat siswa aktif sepenuhnya dalam proses pembelajaran yaitu dengan membuat perubahan pembelajaran yang berpusat pada siswa (student-centredness) (Rahmadani \& Anugeraheni, 2017, hal. 240-241). Dengan demikian, siswalah yang harus mencapai tujuan dari belajar dan yang harus terlibat aktif dalam proses pembelajaran. Dalam proses pembelajaran guru harus melibatkan siswa, terutama melalui mengamati, tanya jawab, mencoba (eksperimen), dan menalar. Selain itu guru harus bisa menciptakan situasi pembelajaran aktif, kreatif, inovatif, efektif, dan menyenangkan dalam proses pembelajaran sehingga siswa tertarik untuk mempelajari materi yang diajarkan. (Hananto \& Ariyanto, 2015, hal. 1). Penggunaan strategi pembelajaran yang tepat dapat meningkatkan motivasi belajar siswa. Siswa yang mempunyai motivasi belajar yang tinggi ratarata hasil belajarnya lebih tinggi dibandingkan yang mempunyai motivasi belajar rendah (Hong, et all, 2007 dalam Hidayat, 2014, hal. $1)$.

Dalam proses pembelajaran di sekolah dasar, matematika adalah salah satu mata pelajaran yang terbukti penting untuk dikuasai para siswa. Menurut the Trends In International Mathematics and Science Study (TIMSS) (Riyanti, 2013, hal.7) memberikan hasil bahwa rata-rata skor matematika siswa Indonesia untuk setiap kemampuan diteliti yaitu kemampuan pengetahuan, penerapan, dan penalaran masih di bawah skor Matematika siswa Internasional. Skor ratarata siswa Indonesia berada pada peringkat 38 dari 42 negara dengan skor rata-rata 386 dari skor tertinggi 613. Pada tahun 2011, skor ratarata siswa Indonesia mengalami penurunan sebanyak 11 poin jika dibandingkan dengan perolehan skor rata-rata pada tahun 2007 yaitu sebesar 397. Fakta ini menunjukkan bahwa kemampuan berpikir siswa Indonesia masih rendah, sehingga perlu adanya upaya untuk meningkatkan kemampuan berpikir siswa.

Beberapa peneliti terdahulu memaparkan hasil penelitian mengenai topik 
serupa yang mana penelitian tersebut memiliki kesamaan yaitu meningkatkan hasil belajar.

Pertama, Wulandari (2012:), dengan judul "Penerapan Model Problem Based Learning Pada Pembelajaran IPA Siswa Kelas 5". Penelitian ini bertujuan untuk mengetahui pengaruh model pembelajaran PBL terhadap proses dan hasil belajar IPA kelas 5 SD. Dari penelitian tersebut dapat diketahui bahwa model Problem Based Learning dapat meningkatkan hasil belajar IPA pada siklus terakhirnya sebesar $72,42 \%$ siswa sudah tuntas. Skor perolehan yang didapat dengan peneraan model PBL meningkat pada setiap siklusnya yaitu 18 pada siklus I, 22 pada siklus II dan 27 pada siklus III. Penerapan Problem Based Learning juga meningkatkan keterampilan proses IPA pada siswa, siswa yang sudah menguasai keterampilan prosesnya 46, $71 \%$ pada siklus I, 76, $19 \%$ pada siklus II, dan $92,06 \%$ pada siklus III.

Selanjutnya, Sukarman (2012) memaparkan hasil penelitian dengan judul "Penggunaan Model pembelajaran Berbasis Masalah (Problem Based Learning) Untuk Meningkatkan Hasil Belajar Matematika Pada Siswa Kelas IV SD Negeri Batiombo 02 Kecamatan Bandar Kabupaten Batang Semester 2/2011-2012”. Hasil belajar mengalami peningkatan, sebelum penelitian ketuntasan hanya $42,85 \%$ dengan rata-rata 5 . Setelah dilakukan tindakan, pada siklus 1 ketuntasan belajar siswa 71,42 dengan ratarata 61,45. Pada siklus 2 ketuntasan belajar Matematika siswa $85,71 \%$ dengan rata-rata kelas 70,47. Berdasarkan penelitian tersebut dapat disimpulkan bahwa dengan penerapan model pembelajaran berbasis masalah (Problem Based Learning) dapat meningkatkan hasil belajar Matematika siswa kelas IV SD Negeri Batiombo 02 Kecamatan Bandar Kabupaten Batang.
Berikutnya Vitasari (2014) yang telah melaksanakan penelitian dengan judul "Peningkatan Keaktifan dan Hasil Belajar Matematika melalui Model PBL Siswa Kelas 5 SD Negeri 5 Kutosari". Penelitian ini menggunakan teknik penelitian tindakan kelas kolaboratif. Subyek penelitian ini adalah siswa kelas 5 berjumlah 16 siswa. Tujuan penelitian ini adalah (1) mendeskripsikan langkahlangkah penerapan model PBL, meningkatkan keaktifan, dan meningkatkan hasil belajar Matematika.

Berdasarkan hasil observasi awal yang dilakukan pada 22 Agustus 2018, motivasi dan hasil belajar Matematika siswa di SDN Kutowinangun 04 Salatiga masih relatif rendah. Hal itu ditunjukkan dari pengamatan yang dilakukan di kelas 5 yang berjumlah 29 siswa. Rendahnya hasil belajar di buktikan dengan dokumentasi yang di berikan oleh guru kelas mengenai hasil nilai ulangan harian bahwa penguasaan materi pada pembelajaran matematika masih kurang maksimal. Penguasaan materi pada KD 4.1 Menyelesaikan masalah yang berkaitan dengan penjumlahan dan pengurangan dua pecahan dengan penyebut berbeda masih di bawah standar KKM yaitu 75. Pada nilai tes formatif yaitu sebanyak 23 tidak tuntas pada muatan matematika khususnya pada materi pada KD 4.1 dari total 29 siswa.

Ada beberapa permasalahan yang muncul, dilihat dari persentase jumlah siswa dibagi total siswa yakni 29 orang. Beberapa kategorinya adalah (1) rendahnya antusias siswa dalam bertanya sebanyak 3 siswa $(10,34 \%),(2)$ rendahnya antusias siswa dalam menjawab pertanyaan sebanyak 4 siswa $(13,79 \%)$, (3) rendahnya siswa yang memiliki kemauan mengerjakan soal di depan kelas sebanyak 3 siswa (10,34\%). Jadi, hasil belajar siswa yang mencapai Kriteria Ketuntasan 
Minimal (KKM) dengan nilai 75 hanya 6 siswa (21\%) dari 29 siswa.

Kondisi tersebut disebabkan oleh beberapa akar penyebab yaitu rendahnya penguasaan materi dikarenakan siswa mempunyai anggapan bahwa pembelajaran muatan Matematika merupakan muatan yang sulit, dalam satu pertemuan siswa terfokus pada muatan yang mereka sukai seperti muatan Bahasa Indonesia dan SBdP. Penyebab lainnya adalah fasilitas penunjang pembelajaran Matematika seperti alat peraga untuk pembelajaran, dan model pembelajaran yang masih konvensional. Hasil belajar Matematika sangat dipengaruhi oleh model pembelajaran yang digunakan oleh guru dalam pembelajaran (Isjoni, 2009, hal 110).

Berdasarkan pada akar penyebab masalah yang dominan pada penelitian ini, dapat diberikan alternatif tindakan dengan menggunakan strategi Problem Based Learning $(P B L)$ dengan berbantuan Card Sort. $P B L$ adalah strategi pembelajaran dengan menghadapkan siswa pada permasalahanpermasalahan praktis sebagai pijakan dalam belajar atau dengan kata lain siswa belajar melalui permasalahan-permasalahan (Suartawan, 2011, hal. 91). Permasalahan yang ada adalah berkaitan langsung dengan kehidupan nyata para siswa. Model PBL ini dirancang untuk mengarahkan siswa untuk berpikir secara kritis dan analitis. Model pembelajaran PBL adalah pembelajaran yang menitik beratkan kepada siswa sebagai pembelajar serta terhadap permasalahan yang otentik atau relevan yang akan dipecahkan dengan menggunakan seluruh pengetahuan yang dimilikinya atau dari sumber-sumber lainnya (Lidnillah, 2013 dalam Fauzia, 2018, hal. 42). Penerapan model Problem Based Learning (PBL) dengan media konkret dapat menjadi upaya dalam meningkatkan hasil belajar Matematika. Hal ini karena model Problem Based Learning(PBL) memunculkan masalah sebagai langkah awal mengumpulkan dan mengintegrasikan pengetahuan baru (Fauzia, 2018, hal. 42). Berbantuan Card Sort (memilah dan memilih kartu) merupakan teknik kegiatan kolaboratif yang dapat digunakan untuk mengajarkan konsep. Dengan demikian kesan yang didapatkan siswa tentang materi pelajaran yang sedang dipelajari lebih kuat, yang pada akhirnya dapat meningkatkan hasil belajar siswa (Silberman, 2009, hal. 149150).

Berdasarkan permasalahan pembelajaran matematika yang diuraikan di atas, maka dilaksanakan sebuah penelitian dengan judul peningkatan hasil belajar matematika melalui model Problem Based Learning (PBL) berbantuan Card Sort siswa kelas 5. Fokus permasalahan dalam penelitian ini yaitu: Apakah melalui model pembelajaran Problem Based Learning (PBL) dapat meningkatkan hasil belajar Matematika pada siswa Kelas 5 SDN Kutowinangun 04 Semester gasal tahun ajaran 2018 atau 2019? Penelitian ini bertujuan untuk mengkaji dan mendeskripsikan peningkatan hasil belajar Matematika pada siswa Kelas 5 SDN Kutowinangun 04 Semester satu Tahun Pelajaran 2018 atau 2019.

\section{Metode Penelitian}

Lokasi penelitian ini di SDN Kutowinangun 04 yang berada di alamat Jl. Butuh, 1 A, Butuh Kutowinangun Kidul, Tingkir, kota Salatiga, Jawa Tengah. Lokasi tersebut terletak satu kompleks dengan SDN Kutowinangun 01 dan SDN Kutowinangun 11.Penelitian ini dilaksanakan pada semester ganjil Tahun Pelajaran 2018 atau 2019 di SDN Kutowinangun 04 kurang lebih selama 4 bulan 
antara bulan September-November 2018 dimulai dari tahap persiapan, pelaksanaan sampai dengan tahap akhir yaitu penyusunan laporan. Penelitian tindakan kelas siklus I dan II masing-masing terdiri dari 3 kali pertemuan yang mana 2 kali tatap muka dan 1 kali tes. Penelitian ini disesuaikan dengan KD muatan Matematika yang sedang diterapkan yaitu materi berupa Bilangan Pecahan (pengurangan dan penjumlahan pecahan, perkalian dan pembagian pecahan) serta menyelesaikan permasalahan sehari-hari yang berkaitan dengan bilangan pecahan.

Subjek Penelitian Tindakan Kelas (PTK) ini adalah kelas 5 SDN Kutowinangun 04 Salatiga Semester I tahun pelajaran 2018 atau 2019 yang berjumlah 29 orang siswa yang terdiri dari 18 siswa laki-laki dan 11 siswa perempuan. Usia siswa kelas 5 antara 10-11 tahun. Jenis penelitian ini merupakan Penelitian Tindakan Kelas (Classroom Action Research) dimana peneliti berkolaborasi dengan guru kelas 5 SDN Kutowinangun 04. Penelitian ini dilakukan untuk perbaikan melalui model pembelajaran PBL (Problem Based Learning) sebagai upaya dalam meningkatkan hasil belajar siswa pada muatan Matematika. penelitian ini mengolah model penelitian tindakan kelas yang telah dikembangkan oleh (Arikunto, 2010, hal 55). Pelaksanaan penelitian ini menggunakan desain penelitian dengan empat (4) tahapan atau siklus yang dilalui, yaitu:

\section{Siklus I}

1. Perencanaan (Planning)

Dari hasil observasi awal dilakukan perencanaan awal yaitu mempersiapkan atau menyusun alat dan bahan, instrumen penelitian seperti: RPP, lembar observasi, dan soal evaluasi. Adapun kegiatan yang dilaksanakan dalam tahap perencanaan adalah: Pemilihan dan menelaah materi muatan Matematika materi Bilangan Pecahan pada Bab 1, yang dilakukan oleh guru kelas.

2. Pelaksanaan (action)

Tindakan dilakukan sesuai RPP yang telah dipersiapkan sebelumnya, dengan menggunakan model pembelajaran PBL berbantuan Card Sort. Dengan kegiatan yang menggali pengalaman para siswa dalam bentuk tanya jawab dengan guru, siswa dilatih untuk berdiskusi dan belajar mempresentasikan pendapat mereka di depan kelas.

3. Pengamatan (Observation)

Pengamatan atau observasi dilakukan bersamaan dengan tindakan pembelajaran. Observasi dilakukan oleh guru observer yang sudah dipilih untuk mengetahui sejauh mana tindakan sesuai dengan rencana yang sudah disusun. Selama observasi peneliti juga mencatat hal-hal yang menjadi kendala dalam tindakan untuk mengetahui apa yang harus ditingkatkan dan dipertahankan agar tujuan penelitian tercapai. Pengumpulan data diperoleh melalui lembar observasi guru dan siswa yang sudah disusun sebelumnya.

\section{Refleksi (Reflection)}

Pada tahap refleksi ini, peneliti dan guru kolaborator menganalisis data yang didapat dari observasi selama kegiatan pembelajaran pada pertemuan 1 hingga pertemuan 3. Analisis dilakukan juga untuk hasil tes yang diberikan di akhir pembelajaran pada Siklus I. Selama tahap 
refleksi ini, peneliti dan guru kolaborator menganalisis dan menyimpulkan data tersebut, apakah dalam penelitian masih ada kendala atau kekurangan, serta apakah terjadi peningkatan hasil belajar siswa. Jika belum ada peningkatan maka akan dilaksanakan perbaikan di siklus II dengan prosedur yang sama dengan siklus pertama. Hasil refleksi ini bertujuan untuk menentukan tindakan yang lebih baik sebagai dasar pertimbangan untuk menyusun rencana kegiatan pada siklus II supaya terjadi peningkatan hasil belajar yang maksimal.

\section{Siklus II}

\section{Perencanaan Tindakan (Planning)}

Perencanaan siklus II dibuat berdasarkan hasil analisis tindakan pada siklus I, dengan maksud untuk mendapatkan informasi kekurangankekurangan yang ada. Informasi inilah yang digunakan untuk menentukan tindakan yang harus dilakukan pada siklus II. Siklus II direncanakan dalam 3 (tiga) kali pertemuan dengan menerapkan pembelajaran PBL berbantuan Card Sort. Kegiatan yang dilaksanakan meliputi menentukan langkah perbaikan yang terjadi pada siklus I, mempersiapkan perangkat RPP dengan menggunakan KD yang berbeda dari KD siklus I. Mempersiapkan alat evaluasi, dan membuat media pembelajaran.

2. Pelaksanaan (Action)

Pelaksanaan tindakan pada siklus II selama 3 kali pertemuan yang terdiri dari kegiatan awal, kegiatan inti, dan kegiatan akhir. Tindakan dilakukan sesuai RPP yang telah dipersiapkan sebelumnya, dengan menggunakan model PBL berbantuan Card Sort.

\section{Pengamatan (Observation)}

Pengamatan dilakukan bersamaan dengan tindakan pembelajaran. Observasi dilakukan oleh guru observer untuk mengetahui keberhasilan penerapan tindakan sesuai dengan rencana yang sudah disusun. Selama observasi guru observer juga mencatat hal-hal yang penting selama proses pembelajaran. Pengumpulan data diperoleh melalui lembar observasi guru dan siswa yang sudah disusun sebelum, selama dan sesudah proses belajar mengajar berlangsung. Fokus pengamatan ditujukan pada interaksi guru dan siswa dalam implementasi pembelajaran PBL berbantuan Card Sort. Observasi selain diarahkan pada proses pembelajaran juga dilihat pada penilaian akhir. Penilaian akhir berguna untuk mengetahui peningkatan hasil belajar muatan Matematika siswa kelas 5 SDN Kutowinangun 04.

\section{Refleksi (Reflection)}

Pada tahap refleksi ini, peneliti dan guru kolaborator menganalisis data yang didapat dari observasi selama kegiatan pembelajaran. Analisis data juga didapatkan dari hasil tes yang diberikan di akhir pembelajaran pada Siklus II. Selama tahap refleksi ini, peneliti dan guru kolaborator mempelajari dan menganalisis kemudian menyimpulkan data tersebut, apakah terjadi peningkatan dalam hasil belajar, kekurangan-kekurangan dalam siklus I apakah sudah diperbaiki dengan benar pada penerapan siklus II, serta kelebihan atau keberhasilan apa yang nampak pada hasil pembelajaran. Jika sudah terjadi peningkatan maka tidak akan dilaksanakan perbaikan pada tahap berikutnya.

Teknik pengumpulan data dalam penelitian menggunakan 3 jenis yaitu tes, 
observasi, dan dokumentasi. Dalam melakukan penelitian ini menggunakan teknik pengumpulan data yaitu:

1) Tes

Tes merupakan alat ukur, prosedur pengukuran yang sengaja dirancang untuk mengukur indikator atau kompetensi tertentu, sehingga hasilnya relatif ajeg bila dilakukan dalam kondisi yang relatif sama (Naniek, 2012, hal. 142). Arikunto (2012, hal. 78) berpendapat bahwa tes merupakan kumpulan pertanyaan atau latihan untuk mengukur apa yang harusnya diukur dalam diri individu atau kelompok. Pada penelitian ini menggunakan tes tertulis dalam bentuk pilihan ganda sebagai alat mengumpulkan data untuk mengukur hasil belajar muatan Matematika pada siswa kelas5 SDN Kutowinangun 04.

2) Dokumentasi

Menurut Arikunto (2006, hal. 158), dokumentasi adalah mencari dan mengumpulkan data mengenai hal-hal yang berupa catatan, transkrip, buku, notulen, rapor, dan sebagainya. Dokumentasi dapat mengungkapkan bagaimana proses pembelajaran dan sikap siswa dalam menerima pembelajaran (Supardi, 2013, hal. 63). Pada penelitian ini metode dokumentasi digunakan untuk memperoleh keterangan berupa catatan penting yang ada keterkaitannya dengan masalah yang akan diteliti. Metode ini digunakan untuk memperoleh daftar atau jumlah siswa dan nilai tes Matematika (nilai evaluasi) dan foto dokumentasi pada saat pembelajaran berlangsung.

\section{3) Observasi}

Sudjana (2011, hal. 84) menyatakan bahwa observasi merupakan alat penilaian untuk mengukur sikap individu ataupun proses terjadinya suatu kegiatan yang dapat diamati, baik dalam situasi yang sebenarnya maupun dalam situasi buatan. Observasi dapat mengukur atau menilai hasil dan proses belajar.

\section{Instrumen Pengumpulan Data hasil Belajar}

Ada 30 butir soal dengan rincian 20 pilihan ganda dan 10 jawaban singkat. 30 butir soal ini akan digunakan sebagai bahan try out yang nantinya dilihat tingkat validitas, reliabilitasnya, dan tingkat kesukarannya. Hasil uji valid dan reliabilitas akan digunakan sebagai soal tes formatif dalam penelitian. Sehingga, menjadi alat ukur yang benar-benar mengukur hasil belajar muatan Matematika dalam penelitian.

\section{Instrumen Pengumpulan Data Proses Belajar}

Lembar observasi digunakan untuk mengukur efektivitas siswa dan guru selama proses pembelajaran menggunakan model Problem Based Learning. Lembar observasi merupakan penilaian yang berupa indikatorindikator untuk mengukur peningkatan aktivitas guru dan siswa. Hasil penilaian yang diperoleh berbentuk skor rata-rata dan deskripsi yang mencerminkan pencapaian aktivitas siswa dan guru selama proses pembelajaran.

Instrumen yang valid berarti instrumen yang dapat digunakan sebagai alat ukur dari apa yang seharusnya di ukur untuk mendapatkan data (mengukur) yang valid (Sugiyono, 2012, hal. 121). Uji validitas instrumen sangat diperlukan agar nantinya apa yang harus diukur benar-benar memiliki alat ukur yang tepat. Uji validitas dilakukan dengan menggunakan bantuan SPSS 16,0 for Windows. Instrumen uji reliabilitas tes berguna untuk mengukur atau menguji kualitas 
alat ukur sebelum digunakan dalam penelitian. Tingkat reliabilitas suatu instrumen menunjukkan kualitas bentuk instrumen. Instrumen penelitian dikatakan baik jika dapat mengukur apa yang akan diukur dan merupakan instrumen yang tepat digunakan untuk mengukur suatu variabel penelitian. Instrumen yang digunakan berupa soal pilihan ganda untuk tes formatif (Siklus I dan Siklus II).

Dalam penelitian ini data-data yang diperoleh dari hasil pelaksanaan PTK pada kelas 5 SDN Kutowinangun 04 berupa data angka (data kuantitatif) dilihat dari nilai evaluasi pra-siklus hingga Siklus II. Data hasil observasi menggunakan analisis data deskriptif kuantitatif yang digunakan untuk menganalisis hasil dari lembar observasi aktivitas guru dan siswa dalam keterlaksanaannya proses pembelajaran menggunakan model $P B L$. Sedangkan teknik analisis deskriptif komparatif digunakan untuk menganalisis data hasil belajar muatan Matematika yakni dengan membandingkan hasil ketuntasan belajar, skor minimal, skor maksimal dan skor rata-rata pra-siklus, siklus I, dan siklus II.

\section{Hasil Penelitian dan Pembahasan}

\section{Hasil}

Data dari analisis hasil belajar matematika pada tes evaluasi siklus I pada pertemuan 3 dengan KD 4.1 Menyelesaikan masalah yang berkaitan dengan penjumlahan dan pengurangan dua pecahan dengan penyebut berbeda yang berkaitan dengan kehidupan sehari-hari, pada materi pecahan memperoleh hasil dengan nilai tertinggi 100 , nilai terendah 46 , nilai rata-rata 72,1 Siswa yang mencapai tuntas KKM hanya 13 siswa
$(44,82 \%)$ dari 29 siswa. Analisis nilai hasil tes formatif siklus I dapat dilihat pada data distribusi frekuensi pada Tabel 1 berikut ini:

Tabel 1. Distribusi Frekuensi Nilai Muatan Matematika Siklus II

\begin{tabular}{|c|c|c|c|}
\hline No. & Interval & Frekuensi & Persentase \\
\hline 1. & $46-54$ & 2 & $7 \%$ \\
\hline 2. & $55-63$ & 2 & $7 \%$ \\
\hline 3. & $64-72$ & 12 & $41 \%$ \\
\hline 4. & $73-81$ & 8 & $28 \%$ \\
\hline 5. & $82-90$ & 4 & $14 \%$ \\
\hline \multirow[t]{2}{*}{6.} & $91-100$ & 1 & $3 \%$ \\
\hline & Jumlah & 30 & $100 \%$ \\
\hline \multicolumn{3}{|c|}{ Nilai Terendah } & 46 \\
\hline \multicolumn{2}{|c|}{ Nilai Tertinggi } & & 100 \\
\hline \multicolumn{2}{|c|}{ Nilai Rata-Rata } & & 72,1 \\
\hline \multicolumn{2}{|c|}{ KKM } & & 75 \\
\hline
\end{tabular}

Ketuntasan belajar siswa pada siklus I dapat dijelaskan bahwa siswa yang memperoleh nilai kurang dari Kriteria Ketuntasan Minimal (KKM 275) sebanyak 16 siswa atau 55,17\% dari jumlah keseluruhan siswa, sedangkan yang sudah mencapai Kriteria Ketuntasan Minimal (KKM $\geq 75$ ) sebanyak 13 siswa dengan persentase $44,82 \%$ dari jumlah keseluruhan siswa. Hasil tersebut menunjukkan bahwa belum ada peningkatan hasil belajar muatan matematika, Dan hasil yang diperoleh tersebut belum memenuhi indikator keberhasilan secara klasikal yang telah ditentukan peneliti sebesar 80\%. Ketuntasan belajar siswa dapat dilihat pada Gambar 1 berikut:

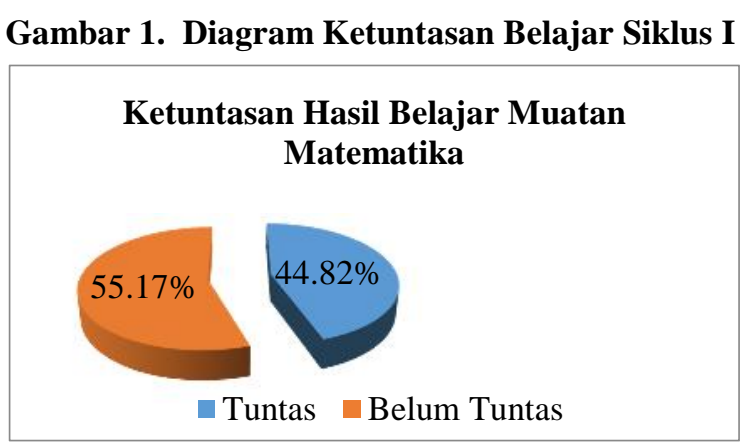


Siswa-siswa tersebut mengalami peningkatan sikap yaitu lebih antusias dan berpartisipasi dalam diskusi maupun Tanya jawab terhadap kelompok lain. Terbukti dari hasil observasi aktivitas siswa pada Tabel 2:

Tabel 2. Distribusi Frekuensi Nilai Muatan Matematika Siklus II

\begin{tabular}{|c|c|c|c|}
\hline No. & Interval & Frekuensi & Persentase \\
\hline 1. & $63-68$ & 2 & $7 \%$ \\
\hline 2. & $69-74$ & 0 & $0 \%$ \\
\hline 3. & $75-80$ & 6 & $21 \%$ \\
\hline 4. & $81-86$ & 9 & $31 \%$ \\
\hline 5. & $87-92$ & 10 & $34 \%$ \\
\hline 6. & $93-100$ & 2 & $7 \%$ \\
\hline & Jumlah & 29 & $100 \%$ \\
\hline & i Terendah & \multicolumn{2}{|c|}{63} \\
\hline & i Tertinggi & \multicolumn{2}{|c|}{100} \\
\hline & i Rata-Rata & \multicolumn{2}{|c|}{84,6} \\
\hline & KKM & \multicolumn{2}{|c|}{75} \\
\hline
\end{tabular}

bahwa dari 29 siswa yang mendapat skor KKM $\geq 75$ sebanyak 26 siswa $(89,65 \%)$ yaitu interval 75-80 sampai 93-100 sebanyak, sedangkan yang belum tuntas berada pada interval skor 63-68 sebanyak 2 siswa $(6,89 \%)$ dari 29 siswa. Meningkatnya aktivitas siswa berdampak pada meningkatnya hasil belajar muatan matematika materi bilangan pecahan. Hal ini dilihat dari peningkatan rata-rata klasikal menjadi 3,16 pada siklus I, dengan ketuntasan mencapai 44,82\% meningkat sebesar $20 \%$ dari ketuntasan hasil belajar pada prasiklus. Namun pencapaian tersebut belum memenuhi indikator keberhasilan yang sudah ditentukan yaitu sebesar $80 \%$ siswa tuntas, maka dilakukannya refleksi untuk dasar tindak lanjut pada siklus II.

Hasil dari perbaikan siklus I yang dilaksanakan pada siklus II, siswa tidak lagi gugup dan ikut serta dalam permainan yang dilaksanakan dalam sintaks membantu penyelidikan mandiri dan kelompok yang berdampak pada ketuntasan belajar siswa secara klasikal yang sudah melampaui indikator ketuntasan $80 \%$. Dapat dilihat pada tabel 4.1 dan 4.2 bahwa perolehan nilai pada siklus II mengalami peningkatan skor rata-rata secara klasikal sebesar 84,6, dengan ketuntasan belajar sebesar $89,65 \%$ seperti pada Gambar 2 di bawah ini.

Gambar 2. Diagram Ketuntasan Belajar Siklus II

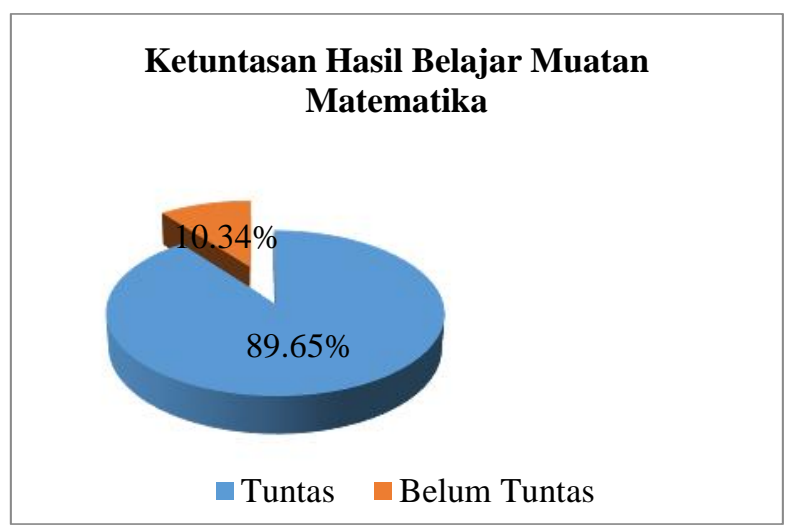

\section{Pembahasan}

Berdasarkan peningkatan pada siklus II, hasil pelaksanaan tindakan telah mencapai indikator keberhasilan yang sudah ditetapkan sebesar $80 \%$ siswa tuntas. Meningkatnya hasil dari siklus I menuju siklus II dikarenakan pada tahap refleksi siklus I sudah diperbaiki pada pelaksanaan tindakan siklus II.

Fokus pada penelitian ini adalah hasil belajar muatan matematika dan proses pembelajaran, akan tetapi selama penelitian berlangsung peneliti menemukan beberapa hal baru, adapun hal baru yang peneliti dapatkan dalam penerapan model pembelajaran PBL berbantuan Card Sort yaitu pada awal pembelajaran perlu dipaparkan suatu permasalahan yang relevan dan familier dengan kehidupan siswa. Pemaparan masalah ini berperan menstimulus siswa untuk tertarik mempelajari materi lebih mendalam. Selain itu penggunaan video pembelajaran juga 
sangatlah membantu siswa untuk memahami materi pelajaran. Pada tes evaluasi siklus II, hasil belajar matematika 26 siswa tersebut sudah mengalami kenaikan, namun 3 siswa dari 29 siswa masih belum tuntas KKM. Faktor yang mempengaruhi ketidak-tuntasan dari 3 siswa tersebut adalah kurangnya pemahaman siswa akan materi bilangan pecahan penjumlahan dan pengurangan yang disampaikan oleh guru dikarenakan ketika proses pembelajaran berlangsung siswa tersebut masih merasa takut dalam bertanya, sehingga dalam menganalisis soal kurang teliti. Dalam pertanyaan yang diajukan oleh guru pada bahasan penjumlahan bilangan pecahan pada siklus II yang dilakukan guru, siswa tidak lagi membutuhkan waktu lama untuk menyelesaikan pertanyaan soal yang diberikan. Karena dalam tahap mengorganisasi siswa untuk belajar siswa dilatih membangun konsepnya sendiri dan menemukan cara baru sesuai kemampuannya dengan bimbingan guru.

Berdasarkan uraian hasil penelitian di atas, menunjukkan bahwa pembelajaran yang dilaksanakan dengan menggunakan model pembelajaran PBL berbantuan Card Sort baik pada siklus 1 dan siklus 2 terbukti dapat meningkatkan hasil belajar muatan matematika Bab 1 pada materi bilangan pecahan baik penjumlahan maupun pengurangan pada bilangan pecahan bagi siswa kelas 5 SDN Kutowinangun 04 pada semester 1 tahun pelajaran 2018/2019. Model PBL berbantuan Card Sort menyebabkan perilaku siswa mulai mengalami perubahan. Perubahan yang terjadi yaitu siswa lebih aktif dan antusias dalam pembelajaran untuk bertanya maupun sekedar berinteraksi. Peran guru sebagi pembimbing dalam pembelajaran PBL berbantuan Card Sort diminta untuk menghidupkan dan memberikan motivasi, agar terjadi proses interaksi aktif yang kondusif. Dengan demikian penggunaan model PBL berbantuan Card Sort dapat melatih cara mengajar guru yang lebih efektif. Maka, penggunaan model pembelajaran yang sesuai, terlebih model PBL berbantuan Card Sort terbukti dapat meningkatkan hasil belajar siswa.

Berdasarkan temuan di atas dapat dilihat bahwa penerapan model PBL berbantuan Card Sort dapat meningkatkan hasil belajar muatan matematika. Hasil penelitian ini sesuai dengan hasil penelitian Vitasari (2014) yang menunjukkan bahwa terdapat peningkatan hasil belajar siswa yang menggunakan $P B L$ lebih baik dengan peningkatan sebesar 29,3\%. Kesimpulan berdasarkan temuan di atas adalah penerapan model PBL dapat meningkatkan hasil belajar muatan matematika pada materi Bilangan pecahan penjumlahan maupun pengurangan bagi siswa kelas 5 SD Negeri Kutowinangun 04 semester 1 tahun pelajaran 2018/2019. Sama halnya dengan penelitian Sukarman (2012)dengan menerapkan model pembelajaran PBL dalam meningkatkan hasil belajar matematika pada siswa mencapai hasil rata-rata $70,47 \%$ dalam kategori baik. Sedangkan dalam penelitian ini ketuntasan belajar mencapai $85,71 \%$.

Dari hasil penelitian tersebut, membuktikan hipotesis sebelumnya bahwa penerapan model pembelajaran PBL berbantuan Card Sort dapat meningkatkan hasil belajar serta berhasil memberikan kontribusi yaitu model pembelajaran PBL dengan menerapkan 5 sintaks utama yang di kembangkan dengan permainan berupa kartu acak (Card Sort) dalam pembelajarannya yang lebih berorientasi kepada siswa. Kontribusi ilmu pada sintaks pertama yaitu siswa di ajarkan mengenai permasalahan yang berkaitan pembelajaran. Pada sintaks ke dua 
mengenal prinsip operasi hitung dengan mencari informasi guna menyelesaikan suatu permasalahan. Pada sintaks yang ke tiga membantu penyelidikan baik mandiri maupun kelompok dengan memecahkan permasalahan pada soal yang di dapat. Sintaks ke empat aktivitas lebih mengarahkan kepada penyajian hasil pekerjaan kelompok dengan mempresentasikannya di depan kelas. Dan pada sintaks ke lima aktivitas lebih mengarahkan siswa untuk berinteraksi lebih aktif melalui penerapan konsep yang mereka dapat dan konsep yang sudah mereka miliki melalui aktivitas komunikatif, seperti tanya jawab, kuis individu maupun kelompok, dan berdiskusi. Berdasarkan uraian tersebut, bahwa model pembelajaran PBL bukan hanya meningkatkan aktivitas dalam pembelajaran, namun diikuti dengan hasil belajar.

\section{Simpulan dan Saran}

\section{Simpulan}

Berdasarkan hasil penelitian dan pembahasan, simpulan yang diperoleh yaitu adanya peningkatan hasil belajar muatan matematika melalui model pembelajaran $P B L$ berbantuan Card Sort melalui pendekatanpendekatan yang disesuaikan dengan pembelajaran muatan matematika serta karakteristik siswa pada kelas 5 SDN Kutowinangun 04 Salatiga terbukti melalui peningkatan skor rata-rata lembar observasi guru dan siswa serta peningkatan skor hasil belajar muatan matematika pada setiap siklusnya. Hasil observasi aktivitas guru pada prasiklus memperoleh rata-rata sebesar 2,08 (cukup), Siklus I memperoleh rata-rata sebesar 3,05 (baik), pada siklus II perolehan rata-rata sebesar 3,57 (baik). Peningkatan juga terlihat pada hasil observasi aktivitas siswa, dibuktikan dengan perolehan awal rata-rata pra siklus II,16 (cukup), selanjutnya rata-rata skor pada Siklus I sebesar 2,97 (cukup), dan Siklus II rata-rata aktivitas siswa 3,44 (baik).

\section{Saran}

Berdasarkan hasil penelitian yang dilakukan di kelas 5 SDN Kutowinangun 04 Semester I tahun Pelajaran 2018/2019, peneliti dapat menyampaikan beberapa saran sebagai berikut :

1. Bagi Guru

Guru yang akan menerapkan model pembelajaran PBL hendaknya menyiapkan semua perangkat dan rencana pembelajaran secara sistematis serta menyenangkan sesuai karakteristik siswa agar dapat tercapai tujuan pembelajaran secara keseluruhan. Pada tahap merefleksikan pengetahuan orientasi peserta didik pada masalah guru sebaiknya lebih memotivasi siswa dan memberikan contoh yang real dalam kehidupan sehari-hari yang dekat dengan siswa, pada tahap membantu penyelidikan mandiri dan kelompok guru sebaiknya memberikan latihan dalam bentuk kegiatan yang menyenangkan seperti mencari, membaca, bermain, dan pada tahap akhir yaitu ekspresi apresiasi pengetahuan (production) guru sebaiknya lebih Menekankan kegiatan yang dapat melatih siswa dalam berbicara atau menyampaikan pendapat hal tersebut dapat mengembangkan rasa percaya diri siswa.

2. Bagi Siswa

Siswa dalam membangun ulang pengetahuan hendaknya lebih berperan 
aktif di dalam pembelajaran khususnya matematika agar pembelajaran lebih komunikatif dan terjadi interaksi yang bagus antara siswa dan pengajar. Hal tersebut berperan serta dalam peningkatan pemahaman saat pembelajaran dan meningkatkan hasil belajar. Siswa yang belum mencapai ketuntasan belajar, disarankan untuk mengikuti bimbingan dan remedi yang diberikan oleh guru. Setelah mengikuti pembelajaran PBL, siswa seharusnya selalu belajar dengan aktif, antusias, kreatif agar dapat memperoleh hasil belajar yang maksimal.

\section{Bagi Sekolah}

Sekolah dalam meningkatkan mutu, sekolah hendaknya lebih mengembangkan lagi sarana dan prasarana yang menunjang dalam kegiatan belajar mengajar seperti media-media pembelajaran inovatif, lab matematika yang dapat membantu guru di dalam menyampaikan materi pembelajaran agar nantinya kualitas peserta didik meningkat.

\section{Bagi Peneliti Lain.}

Peneliti berharap pada penelitian selanjutnya dapat merekonstruksi metode Problem Based Learning ke arah yang lebih baik dengan mampu menjadi wadah bagi para siswa untuk dapat menyalurkan kreativitas siswa ke dalam pembelajaran Matematika sehingga para siswa lebih menekuni dan menguasai Matematika yang pada akhirnya memiliki nilai yang memuaskan.

Demikian simpulan dan saran yang dapat peneliti kemukakan. Semoga peningkatan nilai Matematika para siswa akan terus berkembang dengan metode Problem Based Learning berbantuan Card Sort dan dapat menjadi wadah untuk mengembangkan aspek kognitif serta konstruktif para siswa.

\section{Daftar Pustaka}

Anastasia, W. (2012). Skripsi. Pengembangan Motorik Kasar Melalui Permainan Tradisional Gobak Sodor di TK Pertiwi , Karanganyar.

Arikunto, S. (2010). Prosedur Penelitian Suatu Pendekatan praktik. Jakarta: Rineka Cipta.

Arikunto \&Suharsimi. (2012). ProsedurPenelitian Suatu

Pendekatan Praktik. Jakarta: Rineka Cipta.

Arif, R. (2009). Memahami Pendidikan \& Ilmu Pendidikan.Yogyakarta :Laks Bang Mediatama.

Fauzia. (2018). Penerapan Model Pembelajaran Problem Based Learning Untuk Meningkatkan Hasil Belajar Matematika SD. Model Pembelajaran Problem Based Learning, Hasil Belajar Matematika. Jurnal Primary Program Studi Pendidikan Guru Sekolah Dasar Fakultas Keguruan \& Ilmu Pendidikan Uni5ersitas Riau, 7 (1), 40-47.

Heruman. (2008). Model Pembelajaran Matematika di Sekolah Dasar. Bandung: PT Remaja Rosdakarya.

Hamdani. (2011). Strategi BelajarMengajar. Bandung: C5 Pustaka Setia.

Hananto, R.B., Ariyanto. (2015). Skripsi. Peningkatan Hasil Belajar Matematika Melalui Strategi Pembelajaran Problem Based Learning (PBL) Pada Siswa Kelas 5II A Semester Genap SMP Negeri 02 Kartasura Tahun Pelajaran 2014/ 2015. 
Hidayat, Guntur. (2014). Peningkatan Moti5asi \& Hasil Belajar Matematika Melalui Strategi Problem Based Learning (PTK Bagi Siswa Kelas 5IIA Semester Gasal SMP Negeri 2 Banyudono Tahun 2013/2014). Artikel Publikasi,1-16.

Isjoni. (2009). Cooperative Learning Efektivitas Pembelajaran Kelompok. Bandung: Alfabeta.

Lestari \& Riadi. (2018). Penerapan PBL (Problem Based Learning) Berbantuan Media Papan Catur Untuk Meningkatkan Hasil Belajar Matematika Kelas 4 SD. Jurnal Pendidikan Dasar PerKhasa, 4 (1). 53-62.

Mikhael, G. (2018). Kemampuan Matematika Siswa Indonesia Memprihatikan, Solusinya? Diakses tanggal 15 Maret https://edukasi.kompas.com/read/ 2018/03/21/09211381/kemampua n-matematika-siswa-indonesiamemprihatikan-solusinya

Rahmadani, N., \& Anugraheni, I. (2017). Peningkatan Aktivitas Belajar Matematika Melalui Pendekatan Problem Based Learning Bagi Siswa Kelas 4 SD. Scholaria: Jurnal Pendidikan Dan
Kebudayaan. Diunduh dari: http://ejournal.uksw.edu/scho laria/article/5iew/928/559.

Riyanti. (2012). Kemampuan pemecahan masalah. Diakses tanggal 4 Maret 2019

http://sinriyanti.blogspot.com/201 2/10/kemampuan-pemecahanmasalahmatematis.html

Silberman, M. L. (2009). Active Learning: 101 Cara Belajar Siswa Aktif (Alih bahasa: Raisul Muttaqien). rev.ed. Bandung: Nusamedia.

Sugiyono. (2012). Metode Penelitian Kuantitatif Kualitatif dan $R \& D$. Bandung: Alfabeta

Sukarman. (2012). Penggunaan Model Pembelajaran Berbasis Masalah (PBL) untuk Meningkatkan Hasil Belajar Matematika pada Siswa Kelas IV SD Negeri Batiombo 02. Program S1 PGSD FKIP.

Vitasari, R. (2013). Peningkatan Keaktifan dan Hasil Belajar Matematika Melalui Model Problem Based Learning Siswa Kelas V SD Negeri 5 Kutosari. Forum Penelitian. 